\title{
Somatostatin Receptor Type 2
}

National Cancer Institute

\section{Source}

National Cancer Institute. Somatostatin Receptor Type 2. NCI Thesaurus. Code C17922.

Somatostatin receptor type 2 (369 aa, $\sim 41 \mathrm{kDa}$ ) is encoded by the human SST R2 gene.

This protein is involved in brain development, G protein-coupled receptor signaling, and the inhibition of cell proliferation. 